\title{
Analisis Implementasi Sistem Informasi Manajemen di Instalasi Rawat Jalan Klinik Paru
}

\section{Analysis of Implementation of Management Information System In The Street Installation of The Lung Clinic}

\author{
Tati Sudiarti*, Soedarto Soepangat*, Teguh Wiyono* \\ *Manajemen Rumah Sakit Universitas Respati Indonesia \\ Email : tatisudiarti46@gmail.com \\ RS Paru Cirebon Jl. Pangeran Kejaksaan Cirebon, Jawa Barat
}

\begin{abstract}
ABSTRAK
Kualitas pelayanan yang baik adalah terselenggaranya Sistem Informasi Manajemen Rumah Sakit (SIMRS) yang handal, efektif dan efisien serta upgradeable. Penelitian ini bertujuan untuk mengetahui dan analisis alur dan proses penerimaan SIMRS yang berlangsung di Klinik Paru Rumah Sakit Paru Cirebon. Jenis penelitian ini adalah penelitian Kualitatif, Jumlah informan 11 orang dengan analisa data metode induktif. Hasil penelitian menunjukkan Adanya perbedaan metode mendaftarkan pasien rawat jalan menurut Depkes dengan Klinik Paru Cirebon. Sumber daya manusia yang ada di Instalasi Rawat Jalan Klinik Paru Cirebon pasien masih kurang. Sumber Daya Manusia di unit sistem informasi manajemen rumah sakit yang ada sudah cukup tetapi staff di bagian pengembangan dan pengelolaan aplikasi SIMRS masih kurang. Kompetensi staff dan petugas di pendaftaran masih ada yang belum sesuai dengan kompetensinya. Komputer dan perangkat keras yang ada di Instalasi Rawat Jalan Klink Paru Cirebon masih kurang. Di unit sistem informasi manajemen rumah sakit, komputer dan hardware yang ada sudah cukup. Rumah Sakit Paru Cirebon telah menyelenggarakan sistem informasi manajemen rumah sakit (SIMRS) sesuai dengan Peraturan Menteri Kesehatan Nomor 82 Tahun 2013 dan Keputusan Direktur Rumah Sakit Paru Cirebon tentang penyelenggaraan sistem informasi manajemen rumah sakit.
\end{abstract}

\section{Kata Kunci : Implementasi SIMRS; Instalasi Rawat Jalan.}

\section{ABSTRACT}

The implementation of good service quality is the implementation of a reliable, effective and efficient Hospital Management Information System (SIMRS).This study aims to determine the flow of SIMRS that took place at the Lung Hospital of the Cirebon Lung Hospital. This type of research is qualitative research, 11 informants with inductive data analysis. The results showed that there were differences in the way of registering outpatients according to the Ministry of Health with Cirebon Lung Klink. Human resources in the Cirebon Lung Clinic Outpatient Installation are still lacking. Human Resources in the existing hospital management information system unit is sufficient but staff in the development and management of SIMRS applications are still lacking. Staff and officer competencies in registration are still there that are not in accordance with their competence. Computers and hardware available in the Cirebon Lung Clinic Outpatient Installation are out of patient. In the hospital management information system unit, there are enough computers and hardware. Cirebon Lung Hospital West Java has organized a hospital management information system (SIMRS) in accordance with the Minister of Health Regulation No. 82 of 2013 and the Decree of the Director of the Cirebon Lung Hospital in West Java regarding the organization of a hospital management information system.

Keywords : SIMRS Implementation; Outpatient Installation. 
Tati Sudiarti, Soedarto Soepangat, Teguh Wiyono : Analysis of Implementation of .....

\section{PENDAHULUAN}

Kualitas pelayanan rumah sakit adalah salah satu unsur penting dalam jasa pelayanan kesehatan. Hal ini disebabkan oleh kualitas pelayanan merupakan salah satu indikator yang digunakan untuk mengukur kinerja dari rumah sakit tersebut. Oleh karena itu. kualitas pelayanan harus mendapat perhatian yang serius dari manajemen rumah sakit. Salah satu penunjang terselenggaranya kualitas pelayanan yang baik adalah terselenggaranya Sistem Informasi Manajemen Rumah Sakit (SIMRS) yang handal, efektif dan efisien serta selalu dapat mengikuti perkembangan.

Terselenggaranya Sistem Informasi Manajemen (SIM) bagi suatu rumah sakit merupakan hal yang sangat penting dalam penerapannya di era masa kini. Hal ini didukung dengan semakin kompleksnya permasalahan yang ada dalam data medis pasien maupun data-data administrasi lain yang terkait dengan penyelenggaraan pelayanan rumah sakit yang diterima pasien tersebut. Namun, dalam menyediakan layanan SIM bukanlah hal yang mudah, terutama jika dikaitkan dengan biaya pengadaan SIM yang tidak kecil. Penerapan SIM memerlukan suatu perencanaan yang matang. Bila dilakukan secara tergesa-gesa tanpa melalui tahap perencanaan, dikhawatirkan akan memakan biaya lebih banyak serta beresiko terjadinya kegagalan berfungsinya SIM.

Pelaksanaan SIMRS di Rumah Sakit Paru Cirebon dapat membantu pihak manajemen rumah sakit dalam mengelola secara professional semua sumber daya yang dimiliki dengan menekan prosedur yang tak efisien dan efektif serta boros dari sistem pelayanan kesehatan yang dilaksanakan di rumah sakit tersebut. Disamping itu bahwa di rumah sakit paru Cirebon masih banyak permasalahan dalam pelaksanaan SIMRS dan masih belum berjalan maksimal.

Era pembangunan dan pembaharuan dimana Rumah Sakit Paru Cirebon juga tengah berada di dalam semangat pembaharuan untuk meningkatkan pelayanan kesehatan baik dari sarana maupun prasarana, Sistem Informasi Manajemen Rumah Sakit akan mempunyai tempat yang sangat penting dan bermanfaat sehingga penulis tertarik untuk mengadakan penelitian tentang Analisis Implementasi Sistem Informasi Manajemen Rumah Sakit di Instalasi Rawat Jalan Klinik Paru Rumah Sakit Paru Cirebon Tahun 2018.

\section{METODE}

Desain penelitian yang digunakan adalah kualitatif. Penelitian dilakukan di Rumah Sakit Paru Cirebon pada Juli-Agustus 2018. Informan penelitian ini ditentukan 
berdasarkan purposive sampling. Pengumpulan data dengan cara wawancara mendalam, Focus Grup Discussion, observasi dan telaah dokumen. Variabel yang diteliti meliputi input, (Alur dan proses penerimaan/pendaftaran SIMRS, SDM SIMRS, sarana prasarana) process, Pelayanan Rawat Jalan klinik paru dengan Aplikasi Sistem Informasi Manajemen Rumah Sakit (SIMRS), dan output (peningkatan implementasi SIMRS). Pengolahan data dilakukan dengan cara reduksi data, penyajian data, penarikan kesimpulan dan analisis data menggunakan teknik analisis isi dengan triangulasi sumber dan triangulasi metoda.

\section{HASIL}

\section{Tabel 1. Data Informan}

\begin{tabular}{llllll}
\hline Informan & Jabatan Informan & $\begin{array}{l}\text { Jenis } \\
\text { Kelamin }\end{array}$ & Usia & Pendidikan & $\begin{array}{l}\text { Lama } \\
\text { Kerja }\end{array}$ \\
\hline Informan 1 & Staf Pendaftaran & Perempuan & 37 Tahun & SMA & 10 Tahun \\
Informan 2 & Kasir & Perempuan & 45 Tahun & SMA & 21Tahun \\
Informan 3 & Staf Laboratorium & Perempuan & 45 Tahun & SMK Analis & 20 Tahun \\
Informan 4 & Staf Radiologi & Perempuan & 30 Tahun & D3 & 8 Tahun \\
Informan 5 & Staf Farmasi & Laki-laki & 40 Tahun & D3 & 20 tahun \\
Informan 6 & Staf Poliklinik & Laki-laki & 47 Tahun & D3 & 25 Tahun \\
Informan 7 & Pengelola IT & Laki-Laki & 36 tahun & SI & 17 Tahun \\
Informan 8 & Kepala instalasi rajal & Laki-Laki & 40 tahun & SI & 20 tahun \\
Informan 9 & Kepala Seksi & Perempuan & 45 tahun & SI & 25 Tahun \\
& Pelayanan perawatan & & & & \\
Informan 10 & Kepala Seksi Sarana & Perempuan & 50 tahun & S2 & 3Tahun \\
& Prasarana Perawatan & & & & 2 Tahun \\
\hline
\end{tabular}

Tabel 2. Hasil Wawancara, Observasi dan Telaah Dokumen Alur Pendaftaran Pasien Rawat Jalan Klinik Paru RS Paru Cirebon.

\begin{tabular}{ll}
\hline \multicolumn{1}{c}{ Sumber } & \multicolumn{1}{c}{ Hasil } \\
\hline Wawancara & Alur pendaftaran pasien dimulai dari pengambilan nomor antrian \\
Mendalam & yang sudah di buka sejak pukul 7.00. Pasien umum langsung ambil \\
& nomor antrian kemudian menunggu di loket kasir, sedangkan \\
& pasien BPJS langsung ke loket BPJS, setelah itu pasien menunggu \\
& di poliklinik baik pasien umum maupun BPJS dilakukan assesment \\
& awal pasien oleh perawat. Hasil assesment perawat dibawa ke \\
& klinik tujuan untuk pemeriksaan dokter, selanjutnya atas \\
& rekomendasi dokter dilakukan pemeriksaan penunjang seperti \\
& laboratorium dll, kemudian dilanjutkan pemeriksaan dokter lagi, \\
& hasil di bawa ke unit DOTS selanjutnya ke unit farmasi/apotik, \\
& apabila perlu perawatan, maka dirawat inap, sedangkan yang tidak \\
& perlu langsung pulang. Pada saat di loket pendaftaran, pasien akan \\
& ditanya oleh petugas pendaftaran apakah pasien baru atau pasien \\
& lama. Bila pasien baru maka akan dicetakkan kartu berobat pasien \\
& dan kemudian petugas menginput data pasien ke dalam aplikasi \\
& sistem informasi manajemen rumah sakit. Bila pasien lama petugas
\end{tabular}


Tati Sudiarti, Soedarto Soepangat, Teguh Wiyono : Analysis of Implementation of .....

\begin{tabular}{ll}
\hline \multicolumn{1}{c}{ Sumber } & \multicolumn{1}{c}{ Hasil } \\
\hline & tinggal mencari identitas pasien melalui aplikasi sistem informasi \\
& manajemen rumah sakit di pendaftaran. Untuk pasien dengan \\
& jaminan akan diterbitkan kartu SEP. Setelah itu pasien \\
& dipersilahkan untuk menunggu di poliklinik yang dituju untuk \\
& menunggu antrian pemeriksaan oleh dokter. \\
& Dari data pasien rawat jalan klinik paru yang didapat dari instalasi \\
& rawat jalan klinik paru terlihat bahwa jumlah kunjungan pasien \\
& rawat jalan selama tahun 2017 sejumlah 21.543 pasien, dimana \\
& pasien dengan jaminan (BPJS, Jamkesda, Perusahaan, Gratis) \\
& sejumlah 15.510 pasien merupakan kunjungan pasien terbanyak \\
& dibandingkan pasien umum. \\
& Alur pendaftaran pasien rawat jalan Rumah Sakit Paru Cirebon \\
& dimulai dari pengambilan nomor antrian pasien di mesin nomor \\
Observasi & antrian pasien. Untuk pasien umum langsung mengambil nomor \\
Lantrian, kemudian pasien menunggu di loket untuk pendaftaran. & \\
& Untuk pasien dengan jaminan (BPJS, KIS, Jamkesda) pasien juga \\
& langsung ke loket BPJS. \\
& setelah itu pasien menunggu di poliklinik baik pasien umum \\
& maupun BPJS dilakukan assement awal pasien oleh perawat. Hasil \\
& assement perawat dibawa ke klinik tujuan untuk pemeriksaan \\
& dokter, selanjutnya atas rekomendasi dokter dilakukan \\
& pemerinsaan penunjang seperti laboratorium dll, kemudian \\
dilanjutkan pemeriksaan dokter lagi, hasil di bawa ke unit DOTS & selanjutnya ke unit farmasi/apotik, apabila perlu perawatan, maka \\
dirawat inap. Dengan jumlah pasien yang banyak dan keterbatasan & area saat ini antrian pasien masih panjang. \\
\hline
\end{tabular}

Tabel 3. Hasil Wawancara, Observasi dan Telaah Dokumen Tentang Sumber Daya Manusia.

\begin{tabular}{|c|c|}
\hline Sumber & Hasil \\
\hline $\begin{array}{l}\text { Wawancara } \\
\text { Mendalam }\end{array}$ & $\begin{array}{l}\text { 1. Jumlah SDM di Rumah Sakit paru Cirebon yang mampu } \\
\text { menguasai SIMRS masih terbatas. Hal ini karena kompotensi yang } \\
\text { dimiliki petugas SIMRS belum sesuai dengan bidang yang } \\
\text { dikerjakan. Ketidak sesuai pengetahuan dan ketrampilan bagian } \\
\text { administrasi Klinik Paru Rumah Sakit Paru Cirebon. } \\
\text { 2. Di unit SIMRS saat ini staff yang ada belum cukup, masih banyak } \\
\text { ketergantung pada pihak ketiga yaitu ARSADA dalam menangani } \\
\text { masalah SIMRS. }\end{array}$ \\
\hline $\begin{array}{l}\text { Observasi } \\
\text { Langsung }\end{array}$ & $\begin{array}{l}\text { 1. Jumlah petugas yang melakukan pendaftaran pasien rawat jalan } \\
\text { berjumlah } 8 \text { orang sesuai dengan loket pendaftaran yang } \\
\text { merupakan staff administrasi dan } 1 \text { orang bagian verifikas. } \\
\text { 2. Di unit sistem informasi manajemen rumah sakit sumber daya } \\
\text { manusia yang menangani sistem informasi manajemen rumah sakit } \\
\text { yang saat ini masih menggunakan ARSADA yang ditugaskan. }\end{array}$ \\
\hline $\begin{array}{l}\text { Telaah } \\
\text { dokumen }\end{array}$ & $\begin{array}{l}\text { Unit Sistem Informasi Manajemen Rumah Sakit } \\
\text { a) Kepala SIMRS } \\
\text { a. Sarjana Pendidikan, Magister Science } 1 \text { orang }\end{array}$ \\
\hline
\end{tabular}




\begin{aligned} & \hline Sumber \multicolumn{1}{c}{ Hasil } \\ & \hline b) Koordinator bagian pengembangan dan pengelolaan aplikasi \\ & SIMRS \\ & Sarjana Teknik 1 orang \\ & c) Staf bagian pengembangan dan pengelolaan aplikasi SIMRS \\ & Sarjana Komputer 2 orang \\ & d) Staf bagian pengelola infrastuktur SIMRS \\ & Diploma 2 orang \\ & e) Staf bagian pengelola website dan internet \\ & Diploma 2 orang \\ & f) Staf bagian pengelola media dan informasi \\ & Diploma 1 orang \\ & \hline\end{aligned}

Tabel 4. Hasil Wawancara dan Observasi Tentang Sarana Dan Prasarana

\begin{tabular}{|c|c|}
\hline Sumber & Hasil \\
\hline $\begin{array}{l}\text { Wawancara } \\
\text { Mendalam }\end{array}$ & $\begin{array}{l}\text { 1. Jumlah komputer di setiap unit pelayanan sudah cukup, tetapi } \\
\text { kalau alur kerja pasien di rubah perlu di tambah komputer lagi. } \\
\text { 2. Ruang pendaftaran yang ada saat ini belum cukup menapung } \\
\text { jumlah kunjungan pasien rawat jalan yang banyak, hal ini } \\
\text { terlihat masih panjangnya antrian pasien. Ruang tunggu } \\
\text { pendaftaran pasien juga belum terasa nyaman karena atap ruang } \\
\text { tunggu pendaftaran pasien terasa bisisng bila hujan.Tempat } \\
\text { pendaftaran pasien juga belum sesuai dengan akreditasi, karena } \\
\text { pada saat mendaftar pasien tidak langsung bertatap muka dengan } \\
\text { petugas pendaftaran tetapi mendaftara melalui loket loket } \\
\text { pendaftaran. } \\
\text { 3nit sistem informasi manajemen rumah yanag ada saat ini } \\
\text { masih di bawah Bidang Pengembangan Dan Peningkatan Mutu. } \\
\text { Sehingga ruang unit sisitem informasi manajemen rumah sakit } \\
\text { yang ada di instalasi rawat jalan klinik paru rumah sakit paru } \\
\text { Cirebon masih bergabung dengan Bidang Pengembanagan Dan } \\
\text { Peningkatan Mutu. Sementara untuk ruang penyimpanan server } \\
\text { terpisah dengan ruang unit sistem informasi manajemen rumah } \\
\text { sakit }\end{array}$ \\
\hline
\end{tabular}

Observasi Langsung
1. Ruang pendaftaran yang ada saat ini belum cukup menapung jumlah kunjungan pasien rawat jalan yang banyak, hal ini terlihat masih panjangnya antrian pasien yang panjang. Ruang tunggu pendaftaran pasien juga belum terasa nyaman karena atap ruang tunggu pendaftaran pasien terasa bising bila hujan. Tempat pendaftaran pasien juga belum sesuai dengan akreditasi dan permenkes, karena pada saat mendaftar pasien tidak langsung bertatap muka dengan petugas pendaftaran tetapi pasien harus mendaftar melalui loket loket pendaftaran. Atap ruang tunggu pasien yang ada saat ini belum membuat nyaman pasien, karena selain panas bila hujan akan terasa bising. Begitu pula dengan tempat pendaftaran pasien rawat jalan yang ada saat ini masih berupa loket loket sehingga pada saat mendaftar 
pasien harus membungkukkan badan. Ruang pendaftaran yang ada saat ini juga masih bergabung dengan ruang rekam medis, ini dikarenakan unit pendaftaran saat ini dibawah Instalasi rawat jalan.

2. Unit sistem informasi manajemen rumah sakit yang ada saat ini terletak di lantai atas dari gedung utama dan masih bergabung dengan Bidang Pengembangan dan Peningkatan Mutu. Ruang unit sistem informasi manajemen rumah sakit yang ada saat ini berukuran sekitar 4 x 6 meter persegi. Di dalam ruang sistem informasi manajemen rumah sakit terisi meja meja dengan 1 komputer dan 1 printer. Sedangkan untuk penyimpanan server terpisah dengan ruang sistem informasi manajemen rumah sakit. Ruang server terletak di lantai bawah di bagian belakang dari gedung utama. Ruang penyimpanan sever juga di lengkapai dengan sistem keamanan, sehingga untuk dapat masuk ke dalam ruang server harus orang orang yang mempunyai hak akses ke dalam ruang data atau server.

\section{PEMBAHASAN}

Alur dan proses penerimaan atau pendaftaran SIMRS Instalasi Rawat Jalan, di instalasi rawat jalan Klinik Paru Cirebon saat pasien mendaftar di Tempat Pendaftaran Pasien (TPP), petugas pendaftaran terlebih dahulu akan bertanya kepada pasien, apakah pasien tersebut merupakan pasien baru (pasien yang baru pertama kali datang atau pasien yang belum ada datanya di sistem informasi rumah sakit) atau pasien lama (pasien yang sudah pernah datang atau pasien yang datanya sudah ada dalam sistem informasi rumah sakit). Apabila pasien tersebut pasien baru, maka petugas menginput data pasien (identitas pasien) terlebih dahulu pada biodata pasien, hal ini sesuai dengan Peraturan Menteri Kesehatan Nomor 269 Tahun 2008 Tentang Rekam Medis. Dari hasil penelitian terdapat perbedaan alur pendaftaran pasien antara alur pendaftaran pasien rawat jalan menurut Depkes dengan alur pendaftaran pasien rawat jalan Klinik Paru Cirebon, dimana menurut Depkes pendaftaran pasien rawat jalan dilakukan di sub sistem Tempat Pendaftaran Pasien Rawat Jalan (TPP RJ). Baru setelah itu pendaftaran pasien rawat jalan dibagi menjadi penerimaan pasien baru rawat jalan dan pasien lama rawat jalan. Di rawat jalan klinik Paru Cirebon pasien dibedakan antara pasien umum atau tunai dengan pasien jaminan. Di rawat jalan klinik Paru Cirebon pasien dengan jaminan dilakukan verifikasi berkas terlebih dahulu.

Selain perbedaan alur pendaftaran pasien, terdapat juga perbedaan cara mendaftarkan pasien rawat jalan menurut Depkes dengan rawat jalan klinik Paru Cirebon dimana menurut Depkes pendaftaran pasien rawat jalan baru dimulai dengan mengisi formulir pendaftaran pasien baru sedangkan di rawat jalan klinik Paru Cirebon pasien 
menyerahkan kartu identitas pasien kepada petugas pendaftaran, Menurut Depkes data pada formulir pendaftaran pasien baru diinput pada komputer kemudian mencetak ringkasan riwayat klinik, Sedangkan pada rawat jalan klinik Paru Cirebon data pasien di input ke dalam aplikasi sistem informasi manajemen rumah sakit di dalam menu pendaftaran. Setelah itu baru dicetak kartu pasien bila pasien baru.

Bila pasien lama menurut Depkes melaksanakan transaksi pendaftaran pasien lama dengan mengentri nomor pasien sedangkan di rawat jalan klinik Paru Cirebon pasien menyerahkan kartu identitas pasien kemudian dilakukan pencarian data pasien di aplikasi sistem informasi manajemen rumah sakit di dalam menu pendaftaran. Hasil penelitian menunjukkan klinik Paru Cirebon telah menggunakan aplikasi SIMRS di unit pendaftaran pasien rawat jalan. Sehingga dapat mempermudah di dalam proses pendaftaran pasien.

Dari penelitian sebelumnya yang dilakukan Ronny (2016) berpendapat bahwa: Alur pelayanan pendaftaran pasien rawat jalan dimulai dari pengambilan nomor antrian. Kemudian pasien menunggu di tempat masing-masing loket yang ditentukan, setelah itu antri masing-masing poliklinik, setelah remendasi pemeriksaan dokter dari poliklinik dilanjutkan ke unit farmasi dan kasir sebagai tempat pembayaran pendaftaran pasien umum maupun pasien jaminan yang mengalami biaya tambahan. Terdapat perbedaan alur pendaftaran pasien antara alur pendaftarn pasien rawat jalan menurut Depkes dengan alur pendaftaran pasien rawat jalan Klinik Paru Cirebon, dimana menurut Depkes pendaftaran pasien rawat jalan dilakukan di sub sistem, tempat Pendaftaran Pasien Rawat Jalan (TPP $\mathrm{RJ}$ ), baru setelah itu pendaftaran pasien rawat jalan dibagi menjadi sistem penerimaan pasien baru rawat jalan dan sistem penerimaan pasien lama rawat jalan. Klinik Paru Cirebon alur pendaftaran pasien rawat jalan dibedakan antara pasien umum atau tunai dengan pasien jaminan. Dimana pasien dengan jaminan melakukan verifikasi berkas terlebih dahulu sebelum melakukan pendaftaran di loket pendaftaran, sedangkan pasien umum atau tunai langsung melakukan pendaftaran di loket pendaftaran.

Terdapat perbedaan cara mendaftarkan pasien rawat jalan menurut Depkes dengan Klinik Paru Cirebon dimana menurut Depkes pendaftaran pasien rawat jalan baru dimulai dengan mengisi formulir pendaftaran pasien baru sedangkan di Klinik Paru Cirebon pasien menyerahkan kartu identitas pasien. Menurut Depkes data pada formulir pendaftaran pasien baru diinput pada komputer kemudian mencetak ringkasan riwayat klinik, Sedangkan pada Klinik Paru Cirebon data pasien di input ke dalam aplikasi sistem informasi manajemen rumah sakit di dalam menu pendaftaran. Setelah itu baru dicetak kartu pasien bila pasien baru, bila pasien lama menurut Depkes melaksanakan transaksi 
Tati Sudiarti, Soedarto Soepangat, Teguh Wiyono : Analysis of Implementation of .....

pendaftaran pasien lama dengan mengentri nomor pasien sedangkan di Klinik Paru Cirebon pasien menyerahkan kartu identitas pasien kemudian dilakukan pencarian data pasien di aplikasi sistem informasi manajemen rumah sakit di dalam menu pendaftaran.

Peneliti berpendapat bahwa alur dan proses penerimaan/pendaftaran memang terdapat perbedaan dengan di rawat jalan RS Paru Cirebon dengan Depkes akan tetapi sistem yang berjalan sekarang sudah sesuai dengan kondisi di RS Paru Cirebon.

Menurut "Peraturan Menteri Kesehatan Nomor 82 Tahun 2013 Tentang Sistem Informasi Manajemen Rumah Sakit (SIMRS)”, bahwa rumah sakit harus memiliki unit/instalasi informasi dan teknologi yang terdiri Kepala Instalasi SIMRS dan Staf Informasi dan Teknologi fungsional. Sumber daya manusia informasi dan teknologi terdiri dari staff yang memiliki kualifikasi dalam bidang staf analis sistem, staf programmer, staf hardware, staf maintenance jaringan. Selain kecukupan sumber daya, kompetensi petugas di Instalasi Rawat Jalan Klinik Paru Cirebon belum sesuai dengan kompetensinya. Begitu pula di unit SIMRS kompetensi staff di unit SIMRS masih ada yang belum sesuai dengan kompetensinya. Sehingga perlu adanya kebijakan dari rumah sakit di dalam penempatan tugas pokok dan fungsi.

Menurut penelitian sebelumnya, Cindy (2017) mengemukakan bahwa jumlah petugas yang melakukan kegiatan input data pasien di Tempat Pendaftaran Pasien (TPP) berjumlah 8 orang yang merupakan staff administrasi. Sedangkan sumber daya manusia yang menangani sistem informasi manajemen rumah sakit berjumlah 6 orang yang terdiri dari staf programer, staf hardware dan pelaporan.

Sumber daya manusia yang ada di Instalasi Rawat Jalan Klinik Paru Cirebon pasien masih kurang. Sumber Daya Manusia di unit sistem informasi manajemen rumah sakit yang ada sudah cukup tetapi staff di bagian pengembangan dan pengelolaan aplikasi SIMRS masih kurang. Kompetensi staff dan petugas di pendaftaran masih ada yang belum sesuai dengan kompetensinya. Begitupula dengan kompetensi staff di unit sistem informasi manajemen rumah sakit, masih ada yang belum sesuai dengan kompetensinya.

Diperlukan adanya penambahan petugas SIMRS di pendaftaran atau petugas yang ada diberikan pelatihan dan pendampingan tentang SIMRS yang berkesinambungan, pendampingan dan pelatihan dengan Arsada atau melalui diklat, dapat menggunakan APBD atau BLUD. Komputer dan perangkat keras yang ada di Intalasi Rawat Jalan Klinik Paru Cirebon pasien rawat jalan masih kurang. Di unit sistem informasi manajemen rumah sakit, komputer dan hardware yang ada sudah cukup. Terdapat perbedaan variable modul pendaftaran pasien rawat jalan Klinik Paru Cirebon dengan 
variable modul pendaftaran menurut Permenkes dimana perbedaan itu terlihat di variable pendaftaran melalui telepon.

Klinik Paru Cirebon belum mempunyai variable pendaftaran melalui telepon sehingga perlu adanya pengembangan sistem informasi manajemen rumah sakit di modul pendaftaran pasien. Diharapkan dengan adanya pendaftaran pasien melalui telepon bisa mengurangi antrian pasien yang panjang di loket pendaftaran, dibutuhkan penambahan jumlah komputer dan perangkat keras melalui anggaran BLUD atau dari anggaran APBD.

\section{SIMPULAN}

Adanya perbedaan cara mendaftarkan pasien rawat jalan menurut Depkes dengan Klinik Paru Cirebon dimana menurut Depkes pendaftaran pasien rawat jalan baru dimulai dengan mengisi formulir pendaftaran pasien baru sedangkan di Klinik Paru Cirebon pasien menyerahkan kartu identitas pasien. Menurut Depkes data pada formulir pendaftaran pasien baru diinput pada komputer kemudian mencetak ringkasan riwayat klinik, Sedangkan pada Klinik Paru Cirebon data pasien di input ke dalam aplikasi sistem informasi manajemen rumah sakit di dalam menu pendaftaran. Setelah itu baru dicetak kartu pasien bila pasien baru, bila pasien lama menurut Depkes melaksanakan transaksi pendaftaran pasien lama dengan mengentri nomor pasien sedangkan di Klinik Paru Cirebon pasien menyerahkan kartu identitas pasien kemudian dilakukan pencarian data pasien di aplikasi sistem informasi manajemen rumah sakit di dalam menu pendaftaran. Sumber daya manusia SIMRS yang ada di Instalasi Rawat Jalan Klinik Paru Cirebon pasien masih kurang.

Sumber Daya Manusia di unit sistem informasi manajemen rumah sakit yang ada sudah cukup tetapi staff di bagian pengembangan dan pengelolaan aplikasi SIMRS masih kurang. Kompetensi staff dan petugas di pendaftaran masih ada yang belum sesuai dengan kompetensinya. Begitupula dengan kompetensi staff di unit sistem informasi manajemen rumah sakit, masih ada yang belum sesuai dengan kompetensinya. Komputer dan perangkat keras yang ada di Intalasi Rawat Jalan Klinik Paru Cirebon pasien rawat jalan masih kurang. Di unit sistem informasi manajemen rumah sakit, komputer dan hardware yang ada sudah cukup.

Terdapat perbedaan variable modul pendaftaran pasien rawat jalan Klinik Paru Cirebon dengan variable modul pendaftaran menurut Permenkes dimana perbedaan itu terlihat di variable pendaftaran melalui telepon. Klinik Paru Cirebon belum mempunyai variable pendaftaran melalui telepon sehingga perlu adanya pengembangan sistem 
Tati Sudiarti, Soedarto Soepangat, Teguh Wiyono : Analysis of Implementation of ......

informasi. Manajemen rumah sakit di modul pendaftaran pasien. Diharapkan dengan adanya pendaftaran pasien melalui telepon bisa mengurangi antrian pasien yang panjang di loket pendaftaran.

\section{UCAPAN TERIMA KASIH}

Program Studi Administrasi Rumah Sakit Universitas Respati Indonesia atas bimbingan dan dukungan kepada peneliti.

\section{DAFTAR PUSTAKA}

Alexander Harsono (2015), “Analisis Implementasi Sistem Informasi Manajemen Rumah Sakit Umum Daerah (SIM-RSUD) Terintegrasi Di Provinsi Kalimantan Barat”, Eksplora Informatika Vol. 5, No. 1,

Azwar, Azrul. 1996. Pengantar Administrasi Kesehatan Edisi 3. Binarupa Aksara Jakarta.

Burhan Bungin, 2001. Metodologi Penelitian Kualitatif, edisi satu, Jakarta: Rajawali Pers. CDC.,2013. The Burden. http://www.cdc.gov/HAI/burden.html. (sitasi tanggal 16 Desember 2016 pukul 19.20)

C. Laudon, P. Jane Laudon, Kenneth. 2004. Management Information Systems. Pearson International.

Handiwidjodjo, Wimmie. Jurnal Sistem Informasi Manajemen Rumah Sakit.

Henny Maria Ulfa (2018), "Analisis Unsur Manajemen Dalam Pengolahan Rekam Medis Di Rumah Sakit Tni Au-Lanud Roesmin Nurjadin”, JurnalKesmas Volume 1, No 1.

Jogiyanto, H.M. 2005. Analisa dan Desain Sistem Informasi: Pendekatan Terstruktur Teori dan Praktik Aplikasi Bisnis, Andi, Yogyakarta

Keputusan Menteri Kesehatan Nomor: 129/Menkes/SK/II/2008 tentang Standar Pelayanan Minimal Rumah Sakit

Keputusan Menteri Kesehatan Republik Indonesia No. 340/MENKES/PER/III/2010, "Rumah Sakit

Laudon, Kenneth C dan Jane P. 2004. Management Information System. Managing The Digital Firm. $8^{\text {th }}$ Edition. Peatson Prentice Hall.

P. Jane Laudon, Kenneth C 2004, Manajemen Information Systems, Pearson International.

Laudon, Kenneth C. 2007. Sistem Informasi Manajemen. Jakarta: Salemba Empat, hlm 15.

Oetomo, Budi Sutedjo. 2002. Perencanaan dan Pembangunan Sistem Informasi. Yogyakarta: Andi, hlm 168.

O’Brien, James A. 2005. Introduction to Information System, $12^{\text {th }}$ Edition. McGraw Hill Manulang. (2012). Dasar-dasar Manajemen. Yogyakarta: Gadjah Mada University Press. Munijaya. Manajemen Kesehatan. Jakarta: EGC; 2004.

Muri, 2014. Metode Penelitian Kuantitatif, Kualitatif dan Penelitian Gabungan. Jakarta: Prenadamedia Group

Notoatmodjo, S. (2010). Pengembangan Sumber Daya Manusi. Jakarta: Rineka cipta. PerMenKes RI Nomor 82 Tahun 2013. Sistem Informasi Manajemen Rumah Sakit.

Peraturan Menteri Kesehatan No 82 Tahun 2013, pengaturan SIM-RS

Permenkes No 1171 Tahun 2011, tentang System Informasi Rumah Sakit

Prajitno S. Dasar-dasar Administrasi Kesehatan Masyarakat. Surabaya: Airlangga Press; 2008. 
Rhesavani, P. (2013). Evaluasi Sistem informasi Rekam Medis di RSU PKU.

Rustiyanto, Ery. (2010).Statistik Rumah Sakit Untuk Pengambilan Keputusan. Graha. Ilmu. Yogyakarta.

Sabarguna, Boy S. 2008. Sistem Informasi Rumah Sakit. Yogyakarta: Konsorsium Rumah Sakit Islam Jateng-DIY.

Sabarguna, Boy S. 2005. Logistik RS dan Teknik Efisiensi. Konsorsium RSI Jateng \& DIY. Yogyakarta.

Sugiyono. 2016. Metode Penelitian Kuantitatif, Kualitatif dan R\&D. cetakan ke 24. Bandung: Alfabeta.

Soekidjo Notoatmojo. 2012. Metodologi Penelitian Kesehatan. Jakarta: Rineka Cipta.

Sondakh, Jenny J S dan Marjati dan Pipitcahyani, Tatarini Ika. 2013. Mutu Pelayanan Kesehatan Dan Kebidanan: Salemba Medika.

Tjandra Yoga, Aditama. 2003. Manajemen Administrasi Rumah Sakit. Edisi 2. Jakarta: Penerbit Universitas Indonesia (UI -Press)

Tjiptono, Fandy, Manajemen Jasa, 1996, Andi Offset, Yogyakarta

Undang-Undang RI Nomor 44 Tahun 2009 tentang Rumah Sakit

Wijono, D.2000. Manajemen Mutu Pelayanan Kesehatan Teori, Strategi dan Aplikasi. Surabaya: Airlangga University Press. 